ISSN: 1410-8917

Jurnal Kimia Sains \& Aplikasi

e-ISSN: 2597-9914
Jurnal Kimia Sains dan Aplikasi Journal of Scientific and Applied Chemistry

Journal homepage: http://ejournal.undip.ac.id/index.php/ksa

\title{
Isolation of Flavonoid Compounds from Eceng Gondok (Eichhornia crassipes) and Antioxidant Tests with DPPH (1,1-Diphenyl-2- Picrylhydrazyl) Method
}

\author{
Kautsar Elvira ${ }^{a}$, Enny Fachriyah ${ }^{a,{ }^{*}}$, Dewi Kusrini $^{\text {a }}$ \\ ${ }^{a}$ Chemistry Department, Faculty of Sciences and Mathematics, Diponegoro University, Jalan Prof. Soedarto, Tembalang, Semarang \\ * Corresponding author: enny.fachriyah@live.undip.ac.id
}

https://doi.org/10.14710/jksa.21.4.187-192

\begin{tabular}{l} 
Article Info \\
\hline Article history: \\
Received: 20 August 2018 \\
Revised: 28 October 2018 \\
Accepted: 28 October 2018 \\
Online: 31 October 2018 \\
\hline
\end{tabular}

Keywords:

Eichhornia crassipes;

Eceng gondok;

Flavonoids; Antioxidant

Kata Kunci:

Eichhornia crassipes;

Eceng gondok;

Flavonoid; Antioksidan

\begin{abstract}
The research had been conducted of the isolation of flavonoid compounds from water hyacinth plants (Eichhornia crassipes) and antioxidant activity test by DPPH (1,1diphenyl-2-picrylhydrazyl) method. This research starts from maceration of water hyacinth with ethanol solvent. Ethanol extract was hydrolyzed with $\mathrm{HCl}$. Flavonoid separation is carried out by column chromatography and preparative thin layer chromatography. The obtained isolates were analyzed by UV vis spectrophotometer and FTIR spectrophotometer. Antioxidant activity was carried out by DPPH method. Flavonoid isolates were obtained as heavy as $4.5 \mathrm{mg}(0.006 \%)$. The results of the analysis of flavonoid isolates A4a with UV vis spectrophotometer appear at a wavelength of 368 $\mathrm{nm}$ (band I) and $260 \mathrm{~nm}$ (band II). The results of the analysis with FTIR shown that the isolates had functional groups $\mathrm{O}-\mathrm{H}$, aliphatic $\mathrm{C}-\mathrm{H}, \mathrm{CH} 3, \mathrm{C}=\mathrm{O}$, aromatic $\mathrm{C}=\mathrm{C}$, and $\mathrm{C}-\mathrm{O}$ ether, it was suspected that flavonoid isolates had a basic structure of quercetin 7methyl ether compounds. The results of antioxidant activity test of flavonoid isolates shown $\mathrm{IC}_{50}$ price of $254.66 \mathrm{mg} / \mathrm{L}$
\end{abstract}

\section{Abstrak}

Telah dilakukan penelitian tentang isolasi senyawa flavonoid dari tanaman eceng gondok (Eichhornia crassipes) dan uji aktivitas antioksidan dengan metode DPPH (1,1diphenyl-2-picrylhydrazyl). Penelitian ini dimulai dari maserasi serbuk tanaman eceng gondok dengan etanol. Ekstrak etanol dihidrolisis dengan $\mathrm{HCl}$. Pemisahan flavonoid dengan kromatografi kolom dan klt preparatif. Isolat yang diperoleh dianalisis dengan spektrofotometer UV- vis dan FTIR. Aktivitas antioksidan dilakukan dengan metode DPPH. Isolat flavonoid diperoleh seberat 4,5 mg (0,006\%). Hasil analisis isolat flavonoid A4a dengan UV vis muncul pada panjang gelombang $368 \mathrm{~nm}$ (pita I) dan $260 \mathrm{~nm}$ (pita II). Hasil analisis dengan FTIR, menunjukkan isolat mempunyai gugus fungsi $\mathrm{O}-\mathrm{H}, \mathrm{C}-\mathrm{H}$ alifatik, $\mathrm{CH} 3, \mathrm{C}=\mathrm{O}, \mathrm{C}=\mathrm{C}$ aromatik, dan $\mathrm{C}-\mathrm{O}$ eter, diduga isolat flavonoid memiliki struktur dasar senyawa kuersetin 7-metil eter . Isolat Flavonoid mempunyai $\mathrm{IC}_{50}$ sebesar 254,66 $\mathrm{mg} / \mathrm{L}$.

\section{Pendahuluan}

Eceng gondok (Eichhornia crassipes) dikenal oleh masyarakat luas sebagai tanaman gulma. Eceng gondok memiliki pertumbuhan yang begitu cepat sehingga menutupi permukaan air [1] . Oleh karena itu tantangan bagi manusia untuk mengubah eceng gondok yang berstatus sebagai penggangu menjadi sumber daya yang berguna dan memiliki nilai ekonomi yang tinggi. Penelitian terdahulu melaporkan bahwa pada eceng 
gondok mengandung metabolit sekunder seperti tanin, saponin, flavonoid, steroid, terpenoid, fenol, kuinon, antrakuinon dan alkaloid [2]. Metabolit sekunder dari eceng gondok dilaporkan mempunyai aktivitas antioksidan [3], antitumor [4], penyembuh luka [5], antiinflamasi [6], anti penuaan [7], antialga [8], antijamur [9], antibakteri [10].

Senyawa golongan flavonoid dilaporkan mempunyai aktivitas sebagai antioksidan [11, 12]. Penelitian lain [13, 14] melaporkan bahwa jenis flavonoid yang terdapat pada tumbuhan eceng gondok (Eichhornia crassipes) adalah luteolin, apigenin, trisin, krisoeriol, kaempferol, azaeletin, gossipetin, orientin, kuersetin, dan isovitexin menggunakan metode KLT berdasarkan penampak bercak ammonia pada ekstrak air. Oleh karena itu, pada penelitian ini akan dilakukan isolasi senyawa flavonoid serta identifikasi senyawa flavonoid dari tanaman eceng gondok (Eichhornia crassipes) menggunakan spektrofotometer UV vis dan FT IR serta menguji aktivitas antioksidan menggunakan metode DPPH.

\section{Metode Penelitian}

\subsection{Bahan dan alat.}

Bahan yang digunakan dalam penelitian ini yaitu tanaman eceng gondok, pelarut dengan derajat teknis berupa n-heksana, etanol, etil asetat, pelarut dengan derajat p.a berupa etanol (Merck), etil asetat (Merck), kloroform (Merck), n-heksana (Merck), asam klorida 36\% (Merck), besi (III) klorida (Merck), asam sulfat 98\% (Merck), diklorometan (Merck), amil alkohol, anhidrida asetat, natrium hidroksida, serbuk $\mathrm{Mg}$, pereaksi Dragendorf, pereaksi Mayer, aquadest, amoniak pekat, HCl 2 N, plat silika gel 60 GF254, Silika 60, dan DPPH (1,1-diphenyl-1-picrylhydrazyl) (Sigma-Aldrich) dan kuersetin (Merck).

Alat yang digunakan dalam penelitian ini terdiri alat gelas yang umum digunakan, blender,maserator, kertas saring, seperangkat alat untuk KLT, lampu detektor UV $254 \mathrm{~nm}$ dan $365 \mathrm{~nm}$ (CAMAG UV Cabinet 4), , rotary vaccum evaporator (Buchi-B480), satu set alat kromatografi cair vakum, satu set alat kromatografi kolom gravitasi, neraca analitik (Kern-870), spektrofotometer UV-Vis (Shimadzu UV- 1280), FTIR (Perkin Elmer 10.4.00).

\subsection{Preparasi dan Penapisan fitokimia}

Sampel penelitian berupa tanaman eceng gondok yang diperoleh dari daerah Tembalang, Semarang. Tanaman eceng gondok yang diperoleh dibersihkan, dikeringkan dan dihaluskan menjadi serbuk dan diuji penapisan fitokimia [15].

\subsection{Isolasi Flavonoid}

Sebanyak 2100 gram serbuk tanaman eceng gondok dimaserasi dengan etanol 96\% hingga jernih. Ekstrak yang diperoleh kemudian dievaporasi sampai mendapat ekstrak etanol dan ditimbang. Ekstrak etanol dilarutkan dalam etanol selanjutnya dilakukan penghilangan klorofil dengan menambahkan akuades (1:1), didiamkan selama 24 jam, lalu disaring. Filtrat diekstraksi dengan nheksana.Fraksi etanol-air dihidrolisis dengan $\mathrm{HCl} 2 \mathrm{~N}$ selama 1 jam pada suhu $85^{\circ} \mathrm{C}$ [16]. Fraksi hasil hidrolisis difraksinasi dengan etil asetat hingga didapatkan fraksi etil asetat kemudian dievaporasi untuk menghilangkan pelarutnya lalu ditimbang.

\subsection{Pemisahan Flavonoid}

Fraksi etil asetat sebanyak 1,73 gram dilakukan pemisahan flavonoid dengan kromatografi kolom gravitasi menggunakan fasa diam silika gel 60 dan fasa gerak berupa campuran etil asetat: kloroform : butanol (8:7:2). Eluat-eluat yang dihasilkan dari kolom ditampung setiap $15 \mathrm{~mL}$ dalam botol vial. Masing-masing botol vial dianalisis dengan KLT. Eluat-eluat yang menghasilkan pola noda yang sama digabungkan menjadi fraksi-fraksi besar (fraksi besar A,B,C,dan D) kemudian dilakukan analisis flavonoid menggunakan metode KLT dengan penambahan penampak bercak uap amoniak. Fraksi positif flavonoid dilakukan pemisahan dengan KLT preparatif menggunakan fasa diam plat silika gel 60 F254 ukuran $20 \mathrm{~cm}$ x20 cm, ketebalan 0,5mm-2,0 mm dan fasa gerak berupa campuran n-heksana : etil asetat : butanol (9:5:1) hingga didapatkan isolat flavonoid. Isolat flavonoid yang diperoleh diuji kemurniannya dengan menggunakan KLT berbagai eluen tunggal dan campuran serta KLT dua dimensi dengan eluen campuran.

\subsection{Identifikasi Struktur}

Isolat flavonoid yang telah murni diidentifikasi strukturnya menggunakan spektrofoto meter UV-Vis dan FTIR.

\subsection{Uji Aktiviitas Antioksidan}

Fraksi A hasil kolom dilakukan uji aktivitas antioksidan dengan menggunakan metode KLT. Plat disemprot dengan larutan DPPH 0,1 mM. Pengujian aktivitas antioksidan terhadap fraksi A hasil kolom dilanjutkan dengan metode DPPH dan digunakan kuersetin sebagai pembanding. Fraksi A hasil kolom dibuat variasi konsentrasi 20, 40, 60, 80 dan 100 ppm. Masing-masing konsentrasi dari isolat flavonoid sebanyak 0,2 mL dimasukkan ke dalam botol vial, kemudian ditambahkan 3,8 mL larutan DPPH 0,1 mM. Campuran dihomogenkan dan dibiarkan selama 30 menit dalam ruangan gelap, kemudian diukur absorbansinya pada panjang gelombang $515 \mathrm{~nm}$. Perlakuan yang sama dilakukan terhadap kuersetin dengan variasi konsentrasi $(5,10,15,20$ dan $25 \mathrm{ppm})$. Nilai absorbansi dari larutan uji dengan berbagai konsentrasi digunakan untuk menghitung aktivitas peredaman radikal DPPH (\% inhibisi) dengan menggunakan persamaan berikut [20]

$\%$ inhibisi $=\frac{\text { Akontrol }(\text { DPPH })-\text { Asampel }}{\text { Akontrol }(\text { DPPH })} \times 100 \%$ 
Besarnya aktivitas antioksidan ditentukan dengan nilai IC ${ }_{50}$ yang dihitung dengan menggunakan persamaan yang diperoleh dari kurva regresi linier dengan sumbu $\mathrm{x}$ adalah konsentrasi larutan uji, sedangkan sumbu y adalah persentase aktivitas peredaman radikal DPPH (\% inhibisi). Nilai $\mathrm{IC}_{50}$ merupakan konsentrasi sampel untuk dapat meredam $50 \%$ aktivitas radikal DPPH.

\section{Hasil dan Pembahasan}

Penapisan fitokimia bertujuan untuk mengetahui kandungan senyawa metabolit sekunder yang terkandung dalam tanaman eceng gondok. Hasil penapisan fitokimia dapat dilihat pada Tabel 1.

Tabel 1.Hasil uji penapisan fitokimia serbuk, ekstrak etanol, dan fraksi etil asetat tanaman eceng gondok

\begin{tabular}{|c|c|c|c|}
\hline \multirow{2}{*}{$\begin{array}{l}\text { Senyawa } \\
\text { Metabolit } \\
\text { Sekunder }\end{array}$} & \multicolumn{3}{|c|}{ Bahan } \\
\hline & Serbuk & $\begin{array}{c}\text { Ekstrak } \\
\text { Etanol }\end{array}$ & $\begin{array}{c}\text { Fraksi Etil } \\
\text { Asetat }\end{array}$ \\
\hline Flavonoid & + & + & + \\
\hline Alkaloid & + & & \\
\hline Steroid & + & & \\
\hline Triterpenoid & - & & \\
\hline Saponin & + & & \\
\hline Tanin & + & & \\
\hline Kuinon & - & & \\
\hline
\end{tabular}

Hasil penapisan fitokimia yang diperoleh mirip dengan yang dilaporkan oleh Lata dan Dubey [2] serta Wijaya $d k k$. [3],tumbuhan eceng gondok mengandung steroid, flavonoid, alkaloid, triterpenoid, saponin, kuinon dan tanin.

\subsection{Isolasi Flavonoid}

Serbuk tanaman eceng gondok sebanyak 2100 gram setelah dimaserasi dengan pelarut etanol $96 \%$, disaring dan dievaporasi hingga diperoleh ekstrak kental etanol berwarna coklat kehitaman pekat sebanyak 96,66 gram $(4,6 \%)$. Ekstrak kental etanol setelah dihilangkan klorofilnya menghasilkan fraksi etanol-air, kemudian difraksinasi menggunakan n-heksana. Fraksi etanol-air hasil fraksinasi dihidrolisis dengan metode refluks menggunakan $\mathrm{HCl} 2 \mathrm{~N}$ yang bertujuan untuk memutus ikatan O-glikosida pada kerangka flavonoid, sehingga terbentuk flavonoid bebas dan gula. Flavonoid bebas dalam campuran dapat diambil dengan fraksinasi menggunakan etil asetat. Fraksi etil asetat diuapkan untuk menghilangkan pelarut dan didapatkan fraksi etil asetat sebanyak 1,73 gram $(0,082 \%)$.

\subsection{Pemisahan Flavonoid dan Uji Kemurnian}

Pemisahan flavonoid pada fraksi etil asetat dilakukan menggunakan kromatografi kolom gravitasi dengan fasa gerak etil asetat: kloroform : butanol (8:7:2) dan fasa diam berupa silika gel 60. Eluat yang dihasilkan sebanyak 49 botol vial. Masing-masing botol vial tersebut dianalisis menggunakan KLT dengan fasa gerak etil asetat: kloroform : butanol (8:7:2). Hasil KLT yang mempunyai pola noda yang sama digabung dan diperoleh 4 fraksi besar yaitu fraksi $A, B, C$, dan D seperti yang ditunjukkan pada gambar 2 dan tabel 2.

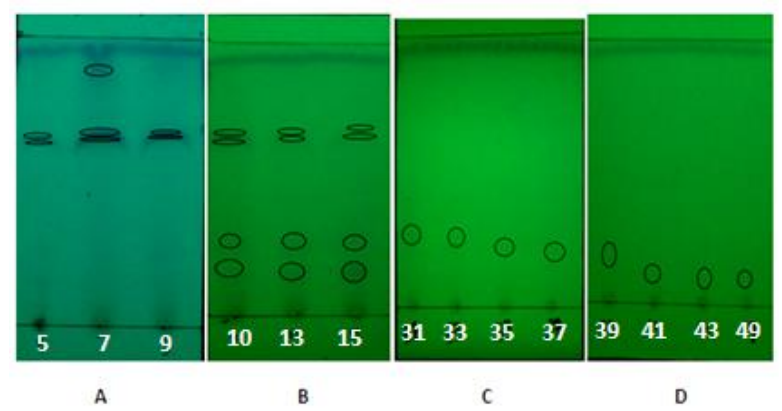

Gambar 1.Profil KLT fraksi A hasil kromatografi kolom gravitasi dengan fasa gerak etil asetat: kloroform : butanol (8:7:2) pada UV $>365 \mathrm{~nm}$

Tabel 2 Profil KLT penggabungan hasil kromatografi kolom gravitasi berdasarkan pola noda yang sama dengan eluen etilasetat:kloroform:butanol (8:7:2) pada UV $\lambda 365 \mathrm{~nm}$

\begin{tabular}{|c|c|c|c|}
\hline No. & Fraksi & $\begin{array}{l}\text { Jumlah } \\
\text { Vial }\end{array}$ & $\begin{array}{c}\text { Wujud dan Warna } \\
\text { Fraksi }\end{array}$ \\
\hline 1 & A & $1-10$ & $\begin{array}{l}\text { Minyak (Coklat } \\
\text { Pekat) }\end{array}$ \\
\hline 2 & B & $11-29$ & $\begin{array}{l}\text { Minyak (Coklat } \\
\text { Pekat) }\end{array}$ \\
\hline 3 & $\mathrm{C}$ & $30-40$ & $\begin{array}{l}\text { Minyak (Kuning } \\
\text { Kecoklatan) }\end{array}$ \\
\hline 4 & $\mathrm{D}$ & $41-49$ & $\begin{array}{l}\text { Minyak (Kuning } \\
\text { kecoklatan) }\end{array}$ \\
\hline
\end{tabular}

Fraksi A, B, C dan D menunjukkan positif flavonoid setelah diberi penampak bercak uap amoniak, namun fraksi A memberikan hasil flavonoid yang lebih dominan dan terlihat jelas dibandingkan fraksi-fraksi lainnya. Fraksi A selanjutnya dipisahkan menggunakan metode KLT preparatif dengan fasa diam plat silika gel60 F254 ukuran $20 \mathrm{~cm}$ x $20 \mathrm{~cm}$, ketebalan 0,5 mm-2,0 mm dan fasa gerak berupa campuran $n$-heksana : etil asetat : butanol (9:5:1). Hasil KLT preparatif fraksi A ditampilkan pada gambar 2.

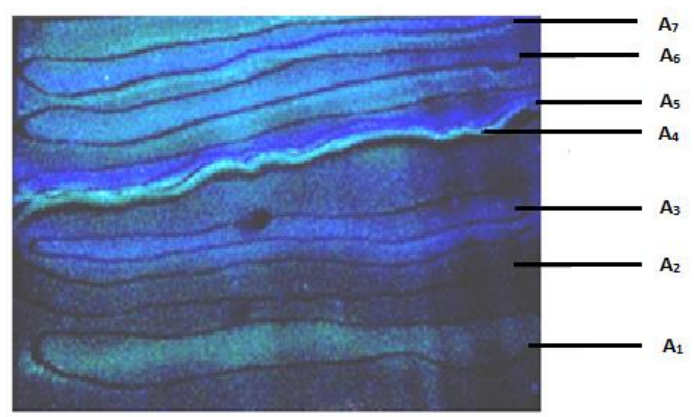

Gambar 2.Profil KLT preparatif fraksi A dengan fasa gerakn-heksana : etil asetat : butanol (9:5:1) padaUV $\lambda$ $365 \mathrm{~nm}$ 
Pita A4 selanjutnya dikerok, dilarutkan dalam etil asetat, dan disaring hingga didapat isolat flavonoid A4. Isolat flavonoid A4 diuji kemurniannya dengan KLT menggunakan campuran eluen $\mathrm{n}$-heksana : etil asetat : butanol (9:5:1) disajikan pada gambar 3.

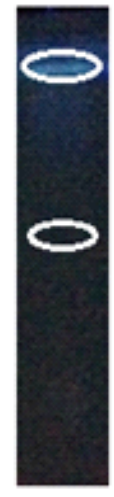

A

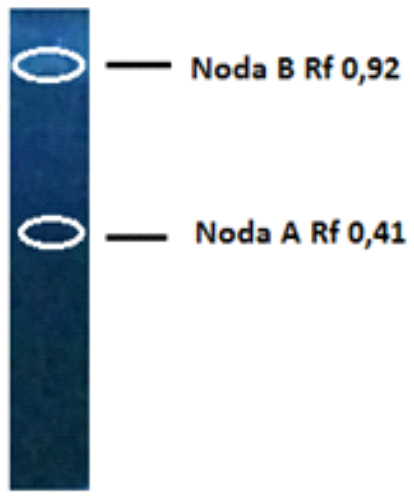

B
Gambar 3.Profil KLT isolat A4 dengan fasa gerak nheksana : etil asetat : butanol (9:5:1) padaUV $\lambda 365 \mathrm{~nm}$. A sebelum penguapan $B$ sesudah penguapan dengan amoniak

Pita A4 kemudian dilakukan KLT preparatif kembali untuk memisahkan noda noda tersebut. Hasil KLT preparatif pita $\mathrm{A} 4$ disajikan pada gambar 4.

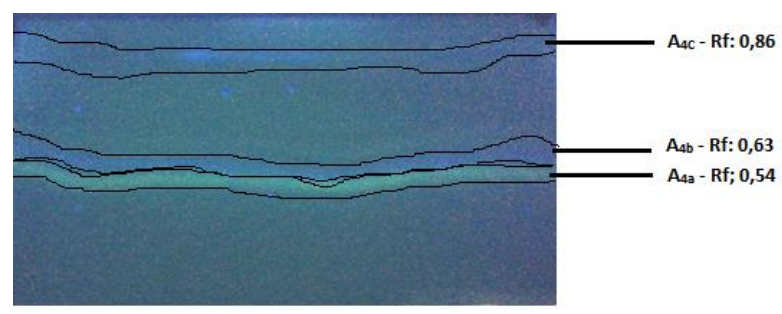

Gambar 4. Profil KLT preparatif pita A4 dengan fasa gerakn-heksana : etil asetat : butanol (9:5:1) padaUV $\lambda$ $365 \mathrm{~nm}$

Pita A4a selanjutnya dikerok, dilarutkan dalam metanol, dan disaring hingga didapat isolat flavonoid A4a. Isolat flavonoid A4a diuji kemurniannya dengan KLT menggunakan berbagai eluen disajikan pada gambar 5 .

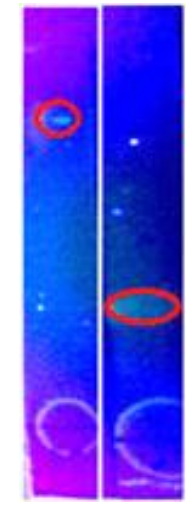

A B

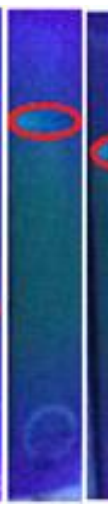

C

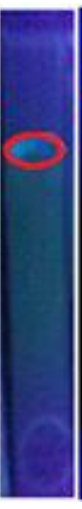

$\mathrm{D}$

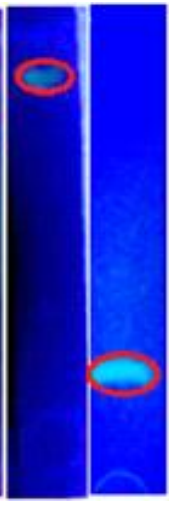

E $\quad F$
Gambar 5. Profil KLT isolat flavonoid A4a isolat flavonoid A4a pada uji kemurnian dengan berbagai fasa gerak pada UV $\lambda 365 \mathrm{~nm}$.
Keterangan: Fasa gerak $(\mathrm{A})=$ etil asetat, $(\mathrm{B})=$ kloroform, $(\mathrm{C})=$ butanol, $(\mathrm{D})=$ n-heksana:etil asetat:butanol (9:5:1), (E) = butanol kloroform $(1: 4),(F)=$ kloroform + uap amoniak

Hasil KLT preparatif isolat flavonoid A4a dilakukan KLT dua dimensi seperti disajikan pada gambar 6.

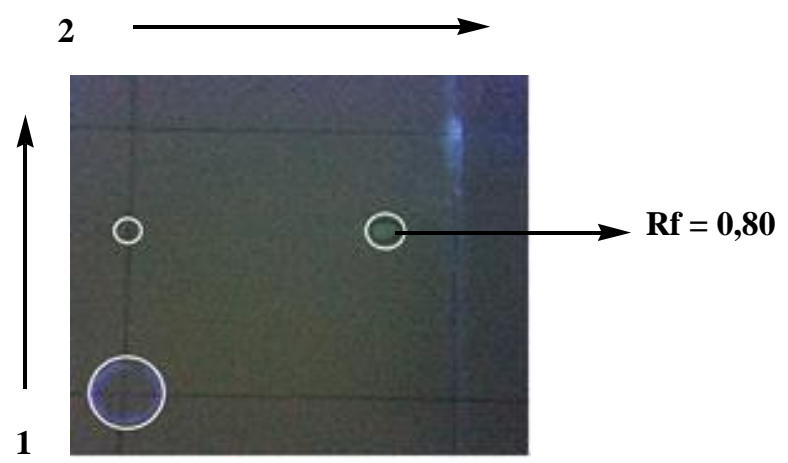

Gambar 6. Profil KLT dua dimensi isolat flavonoid A4a pada UV 入 $365 \mathrm{~nm}$. Keterangan : 1. Eluen Butanol : kloroform (1:9) 2. Eluen Butanol : kloroform (1:4)

Pada gambar 5 dan 6, terlihat hasil KLT menunjukkan noda tunggal. Hal ini diduga bahwa isolat flavonoid A4a telah murni.Noda pada KLT dua dimensi berwarna flouresensi hijau kekuningan setelah diberi penampak bercak uap amoniak yang diduga isolat flavonoid A4a termasuk ke dalam flavonoid jenis flavonol, sesuai dengan tabel penafsiran warna bercak dari segi struktur flavonoid [17]. Isolat flavonoid $\mathrm{A}_{4} \mathrm{a}$ diuapkan dan diperoleh isolat flavonoid sebanyak 0,0045 gram.

\subsection{Identifikasi Struktur Flavonoid}

Isolat flavonoid A4a dilarutkan dalam metanol, kemudian dianalisis menggunakan spektrofotometer UV-Vis dan diperoleh spektrum yang disajikan pada gambar 7 .

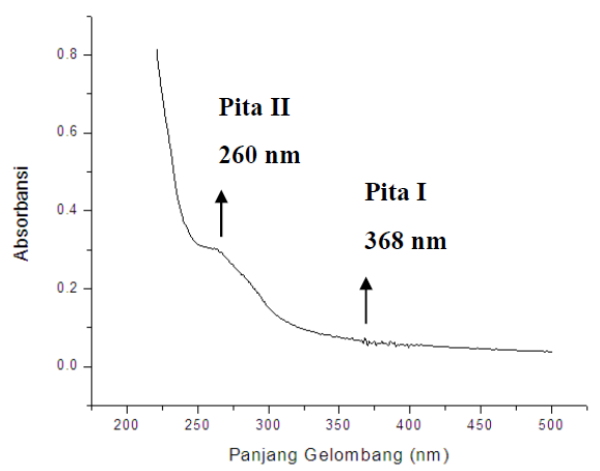

Gambar 7. Spektrum UV-Vis isolat flavonoid A4a dalam metanol

Isolat flavonoid A4a dianalisis menggunakan spektrofotometer UV-Vis menghasilkan dua serapan panjang gelombang, yaitu pita I ( $368 \mathrm{~nm}$ ) dan pita II ( 260 nm). Pita I pada flavonoid menunjukkan absorbsi pada cincin B sinamoil dan pita II adalah absorbsi cincin A benzoil. Hasil analisis isolat A4a dengan UV vis 
memberikan puncak pada pita I yang relatif sangat rendah (368 nm) dibandingkan pita II (256 nm), karena konsentrasi yang sangat kecil. Hal ini karena keterbatasan isolat yang diperoleh. Menurut [17] dilihat dari spektrum yang diperoleh diduga isolat flavonoid $\mathrm{A} 4 \mathrm{a}$ memiliki struktur dasar senyawa flavonol, karena flavonol memiliki rentang serapan pita I $(350-380 \mathrm{~nm})$ dan pita II $(250-280 \mathrm{~nm})$. Hal ini sesuai dengan hasil identifikasi awal menggunakan KLT dengan diberi uap amoniak. Menurut penelitian [13, 14], jenis flavonoid yang terdapat pada tanaman eceng gondok (Eichhornia crassipes) adalah luteolin, apigenin, trisin, krisoeriol, kaempferol, azaeletin, gossipetin, orientin, kuersetin, dan isovitexin menggunakan metode KLT dan kromatografi kertas. Peneliti lain [18] telah melakukan penelitian mengenai kuersetin 7-metil eter yang dianalisis menggunakan spektrofotometer UV-Vis. Kuersetin 7-metil eter memiliki panjang gelombang pada pita I (372 nm) dan pita II (256 nm). Spektrum isolat flavonoid A4a mempunyai kemiripan dengan spektrum UV vis dari kuersetin-7-metil eter yang dilakukan oleh Ferraro $d k k$. [18].

Analisis selanjutnya adalah dengan menggunakan spektroskopi FTIR. Hasil analisis isolat A4a dengan spektrofootometer FT IR disajikan pada gambar 8

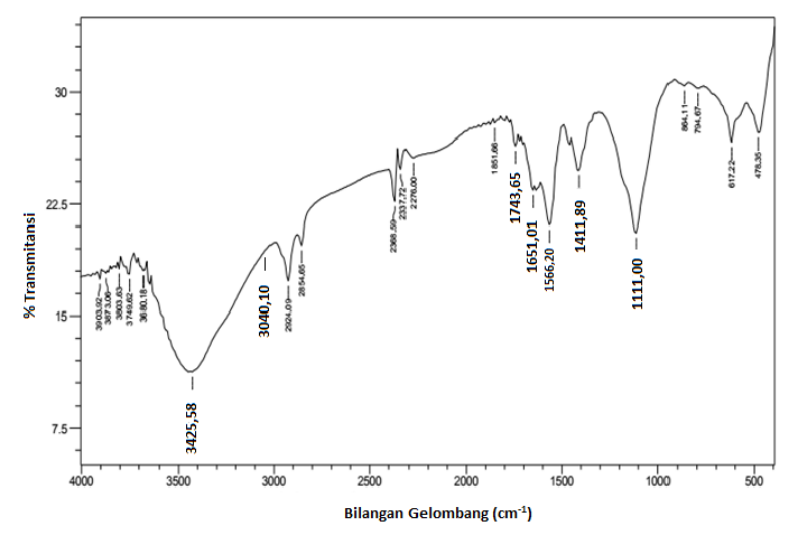

Gambar 8. Spektrum FTIR isolat flavonoid A4a

Dari hasil analisis isolat flavonoid A4a memiliki pita serapan pada bilangan gelombang 3425,58 $\mathrm{cm}^{-1}$ menunjukkan adanya vibrasi ulur $\mathrm{O}-\mathrm{H}$ yang dapat membentuk ikatan hydrogen.Pita serapan pada bilangan gelombang 3040,10 cm-1 dan 1651,01 cm $\mathrm{cm}^{-1}$ menunjukkan vibrasi ulur $=\mathrm{C}-\mathrm{H}$ dan vibrasi ulur $\mathrm{C}=\mathrm{C}$ aromatik yang menunjukkan adanya struktur benzena. Pita serapan pada bilangan gelombang $1743,65 \mathrm{~cm}^{-1}$ menunjukkan adanya vibrasi ulur $\mathrm{C}=\mathrm{O}$, pita serapan pada bilangan gelombang 1411,89 $\mathrm{cm}^{-1}$ menunjukkanvibrasi tekuk $\mathrm{CH}_{3}$, pita serapan pada bilangan gelombang 1111,00 $\mathrm{cm}^{-1}$ menunjukkan vibrasi ulur C-O eter (jembatan 0) [19].

\subsection{Uji Aktivitas Antioksidan}

Hasil aktivitas antioksidan fraksi A hasil kolom menunjukkan perubahan warna dari ungu menjadi kuning pada noda yang ditunjukkan pada gambar 9.

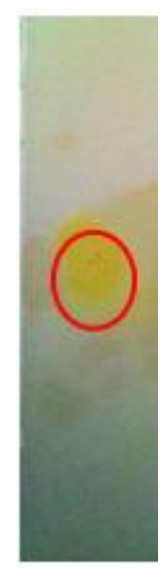

Gambar 9. Hasil uji aktivitas fraksi A hasil kolom pada sinar tampak

Penentuan aktivitas antioksidan dilanjutkan dengan menggunakan metode DPPH (1,1-difenil-2pikrilhidrazil) terhadap fraksi A hasil kolom dan kuersetin sebagai pembanding. Flavonoid akan menghambat aktivitas radikal bebas dari DPPH karena memiliki kemampuan untuk mendonorkan radikal protonnya yang akan menyebabkan terjadinya reduksi membentuk DPPH nonradikal. Reaksi peredaman radikal bebas oleh flavonoid yang mungkin terjadi dapat dilihat pada gambar 10.

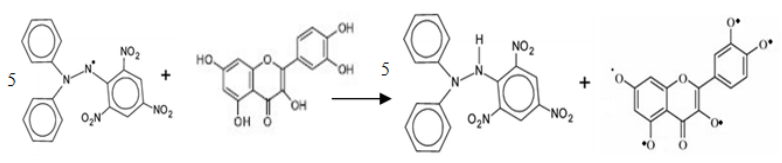

Gambar 10. Reaksi peredaman radikal bebas oleh flavonoid [20]

Parameter uji aktivitas antioksidan adalah Inhibition Concentration $\left(\mathrm{IC}_{50}\right)$ yaitu konsentrasi suatu zat antioksidan yang menyebabkan 50\% DPPH kehilangan karakter radikal atau konsentrasi suatu zat antioksidan yang memberikan persentase penghambatan sebesar $50 \%$. Harga $\mathrm{IC}_{50}$ dapat dilihat pada tabel 3.

Tabel 3. Harga $\mathrm{IC}_{50}$ fraksi A hasil kolom dan kuersetin pada panjang gelombang maksimum $515 \mathrm{~nm}$

\begin{tabular}{cc}
\hline Sampel & $\mathrm{IC}_{50}(\mathrm{mg} / \mathrm{L})$ \\
\hline Fraksi A & 254,66 \\
Kuersetin & 23,2419 \\
\hline
\end{tabular}

Hasil uji aktivitas antioksidan menunjukkan bahwa fraksi A hasil kolom memiliki aktivitas antioksidan yang lebih rendah dari kuersetin. Harga IC $_{50}$ yang baik yaitu di bawah $200 \mathrm{mg} / \mathrm{L}$ [20], oleh karena itu dapat disimpulkan bahwa fraksi A hasil kolom memiliki aktivitas antioksidan, meskipun kurang kuat. Tingginya aktivitas antioksidan pada kuersetin disebabkan kuersetin yang digunakan merupakan senyawa murni yang mempunyai kemampuan lebih besar untuk mendonorkan protonnya. Gugus hidroksil sangat berperan dalam meredam radikal bebas dengan cara mendonorkan protonnya. 


\section{Kesimpulan}

Isolat flavonoid dari tanaman eceng gondok (Eichhornia crassipes) diperoleh seberat 0,0045 gram $(0,006 \%)$. Identifikasi isolat flavonoidA4a tanaman eceng gondok menggunakan spektrofotometer UV-Vis dan FTIR menunjukkan bahwa isolat tersebut diduga merupakan flavonoid golongan flavonol jenis kuersetin7-metil eter. Fraksi A hasil kolom fraksi etil asetat tanaman eceng gondok memiliki aktivitas antioksidan ditunjukkan oleh harga $\mathrm{IC}_{50}$ sebesar 254,66mg/L.

\section{Daftar Pustaka}

[1] Ahmed M. Aboul-Enein, Ahmed M. Al-Abd, Emad Shalaby, Faten Abul-Ela, Amr A. Nasr-Allah, Ali M. Mahmoud, Hany A. El-Shemy, Eichhornia crassipes (Mart) solms: from water parasite to potential medicinal remedy, Plant signaling \& behavior, 6, 6, (2011) 834-836 http://dx.doi.org/10.4161/psb.6.6.15166

[2] N Lata, Venapani Dubey, Preliminary phytochemical screening of Eichhornia crassipes: the world's worst aquatic weed, Journal of pharmacy Research, 3, 6, (2010) 1240-1242

[3] Dianty Wijaya, Putri Purnama Yanti, Muhammad Rizal, Screening Fitokimia dan Aktivitas Antioksidan Daun Eceng Gondok (Eichhornia crassipes), Jurnal Kimia VALENSI, 1, 1, (2015) 65-69

[4] Huma Ali, Meha Patel, N Ganesh, Janak Ahi, The world's worst aquatic plant as a safe cancer medicine-Antitumor activity on melanoma induced mouse by Eichhornia crassipes: in vivo studies, Journal of Pharmacy Research, 2, 8, (2009) 1365-1366

[5] Huma Ali, N Lata, Janak Ahi, N Ganesh, Evaluation of wound-healing activity of Eichornia crassipes: A novel approach, Drug Invention Today, 2, 3, (2010) 212-214

[6] P Jayanthi, P Lalitha, R Sujitha, A Thamaraiselvi, Anti-inflammatory activity of the various solvent extracts of Eichhornia crassipes (Mart.) Solms, International Journal of PharmTech Research, 5, 2, (2013) 641-644

[7] Pottail Lalitha, Jayanthi Ponnusamy, Antiaging activity of the skin cream containing ethyl acetate extract of Eichhornia crassipes (Mart.) Solms, International Journal of PharmTech Research, 6, 1, (2014) 29-34

[8] Sanaa MM Shanab, Emad A Shalaby, David A Lightfoot, Hany A El-Shemy, Allelopathic effects of water hyacinth [Eichhornia crassipes], PLoS One, 5, 10, (2010) e13200

[9] Varaprasad Bobbarala, Prasanth Kumar Katikala, K. Chandrasekhar Naidu, Somasekhar Penumajji, Antifungal Activity of Selected Plant Extracts against Phytopathogenic Fungi Aspergillus niger F2723, Indian Journal of Science and Technology, 2, 4, (2009) 87-90

[10] Mahavir Joshi, Sandeep Kaur, In Vitro Evaluation of Antimicrobial Activity and Phytochemical Analysis of Calotropis Procera, Eichhornia Crassipes and Datura
Innoxia Leaves., Asian Journal of Pharmacy Clinical Research, 6, Supplemen 5, (2013) 25-28

[11] G.E. Trease, W.C. Evans, A Text-Book of Pharmacognosy, Bailliere Tindall Ltd., London, 1989.

[12] Narayana K. Raj, Reddy M. Sripal, M. R. Chaluvadi, D. R. Krishna, Bioflavonoids classification, pharmacological, biochemical effects and therapeutic potential, Indian Journal of Pharmacology, $33,1,(2001) 2-16$

[13] B. L. Nyananyo, A. H. Gijo, E. N. Ogamba, The Physico-chemistry and Distribution of Water Hyacinth (Eichhornia cressipes) on the river Nun in the Niger Nelta, Journal of Applied Sciences and Environmental Management, 11, 3, (2007) 133-137 http://dx.doi.org/10.4314/jasem.v11i3.55158

[14] P. Lalitha, S. K. Sripathi, P. Jayanthi, Secondary metabolites of Eichhornia crassipes (Waterhyacinth): a review (1949 to 2011), Nat Prod Commun, 7, 9, (2012) 1249-1256

[15] Norman R. Farnsworth, Biological and phytochemical screening of plants, Journal of Pharmaceutical Sciences, 55, 3, (1966) 225-276 http://dx.doi.org/10.1002/jps.2600550302

[16] Safira Safira, Enny Fachriyah, Dewi Kusrini, Isolasi dan Identifikasi Senyawa Flavonoid dari Ekstrak Etil Asetat Rimpang Bengle (Zingiber cassumunar Roxb.), Jurnal Kimia Sains dan Aplikasi, 15, 1, (2012) 3 http://dx.doi.org/10.14710/jksa.15.1.36-38

[17] KR Markham, Cara Mengidentifikasi Flavonoid, ITB, Bandung, 1988.

[18] Graciela Ferraro, Filip Rosana, María A del Pero, Norma Basualdo, Rodolfo Mendoza, Ileana García, Flavonoids of Lotus tenuis (Waldst. \& Kit.) as markers of populations growing in soils of different saline and hydrologic conditions, Journal of the Brazilian Chemical Society, 21, 9, (2010) 1739-1745

[19] Robert M Silverstein, G Clayton Bassler, Terence C Morrill, Spectroscopic identification of organic compounds, Wiley, New York, (1981) 196

[20]Philip Molyneux, The use of the stable free radical diphenylpicrylhydrazyl (DPPH) for estimating antioxidant activity, Songklanakarin Journal of Science and Technology, 26, 2, (2004) 211-219 